\title{
COMMENT
}

\section{Thinking about neo-liberalism as if specificity mattered}

\author{
Donald M. Nonini
}

It is always a pleasure to read John Clarke's work because, like the analytical "ordinary language" philosophers of the 1950s to 1970s, such as Wittgenstein and Austin, he pushes all of us who use the concepts he examines to think more rigorously about what we mean by them and by our theoretical assumptions when we use them. The present essay is no exception, and I learned much from it as a tour d'horizon of current thinking about neo-liberalism by social scientists. The observations that John makes about the ways in which current scholars view neo-liberalism as promiscuous, omnipresent, and omnipotent are spot-on.

Unfortunately, unlike the ordinary language philosophers, John has examined neo-liberalism worldwide without sufficient attention to examples in specific places and times to help us perceptively think through what is going on. Perhaps it is the empiricist in me coming out, but I feel that the world is a far too heterogeneous place to think about without disciplining our theoretical concepts through specific applications to cases that may illuminate their limitations. I am sure that John shares this sentiment with me, but the problem in this essay is that in it John thinks in general about the virtues of thinking specifically through examples (with, as he points out, all the contradictions, tensions, and stresses they bring up), but the result is that he still ends up thinking only in general, and this at times compounds confusions rather than illuminates them.

This leads to my first point. One can't think through what neo-liberalism is, until and unless one has thought through what it is not. This is a crucial diacritical exercise. What societies do not show neo-liberal characteristics, what are the configurations of political cultures, governing logic, and class rule that coexist with neoliberalism but are not dominated by it? John of course is well aware of this, but I do not think he has adequately confronted its implications. For example, John quite correctly asks us to think of neo-liberalism as open, unfinished, rife with contradictions, tensions, and ambivalences, because he says this "announces the possibility of thinking about what is not neo-liberal ... and thus the possibility of living without neo-liberalism" (p. 145). But one should beware of what one wishes for. Despite some progressive alternatives, I can also think of several past and contemporary examples of non-neo-liberal forms of governance that are hardly desirable (e.g., fascism, predatory oligarchy, regional mafias), as long as one is willing to argue, as I am, that neo-liberalism is not omnipotent, and does not (contra Bondi and Laurie 2005) affect, much less infect, all spaces in the world. Moreover, one must be able to say that there are places that 
have experienced neo-liberalism, but rejected it in profound ways, as in some countries in South America recently. To seriously believe in the omnipotence and agentic omnipresence of neoliberalism is a kind of Hegelianism, not social science. I will come back to this later.

What is neo-liberalism? John begins to show us what is at stake only well into the essay, when he provides a sufficiently robust definition of neo-liberalism in general-a "coherence" "provided by the combination of a logic of market rationality, a conception of personhood (centered on, but not exclusive to, human individuals), a calculating framework of efficiency, and a view of authority as a fundamental political and social bond" (p. 141). Indeed in my research with others (Holland, Nonini, et al. 2007) on local politics in the United States, this appears to be a workable definition of what we observed in five different ethnographic sites. We found that their local economic and political elites were enchanted by neo-liberal thinking in their economic development strategies to attract capital, their virtual idealizations of competitive places, and their creation and operation of "publicprivate partnerships" (Holland, Nonini, et al. 2007). We also found Dagnino's (2005) "perverse confluence" that allowed non-neo-liberal imaginaries room for flourishing. We discovered the social justice imaginary of many poor African-Americans, as well as that of white supremacy in the case of the "Christian identity" movement in one of the sites we studied. Such groups were subordinate to neo-liberalism in the sense that they were aware of being subordinate in their class and racial position in US society to local elites-not because they accepted neo-liberal views or practices, or found themselves subject to calculative technologies. But we did find, for example, that environmental justice and social-justice activists competed with one another for sources of foundation and government funding for their projects (one sign of a dominant neo-liberalism), yet they did not attack other activists who also sought funding, and instead saw this competition as the working out of mechanisms of racial and class exclusion, or conversely, as providing new opportunities to support their projects (Holland, Nonini, et al. 2007). Neo-liberalism is always contingent and can never completely close down alternatives.

This brings me to the second point I wish to make. There is an insufficiently theorized conception in John's essay about power. Despite manifestations in the examples that John alludes to, I am wondering why there is no mention of class power-and state power connected to class domination (in the tense, contradictory, and ambivalent ways John alludes to)-in neo-liberal governance? Certainly, class rule is consistent with what we found in our research on local politics in the US. John makes no mention of the concept of hegemony (Gramsci 1971) anywhere in his essay. I am wondering what happened to the idea of neo-liberalism as a hegemonic project that we find, for example, in Stuart Hall's (1988) work, The Hard Road to Renewal, in which Hall sets out his analysis of authoritarian populism? In Hall's work, concepts such as historic bloc, economic dominance, passive revolution, crisis, and popular consent do an important kind of work in his reconstruction of how Thatcherism came to achieve a hegemony that combined neo-liberal with neo-authoritarian elements. Yet, it was a hegemony in which discourses were associated with class position, ${ }^{1}$ and hegemony associated with class domination. ${ }^{2}$ I would like to propose not that Hall got everything right in the case of authoritarian populism, but that if we want to understand something about neoliberalisms in their travels, Hall's study provides a model for investigating the processes by which neo-liberalisms can become dominant, in that their advocates seek to constitute an historic bloc, to successfully tie economic domination to intellectual and political domination, and to achieve hegemony. ${ }^{3}$ And what of neo-liberalisms in Britain, the US, and elsewhere as doctrinal bases for utopian social movements (Gray 2007), with all this suggests about activist networks, knowledge, and so on? As Hall and no doubt John himself would be the first to argue, this implies that a neo-liberalism may not become hegemonic, and this is what I want to turn to in conclusion. 
It is not only imaginable, but indeed possible, that neo-liberalism is not dominant in specific political formations, or may have little influence on them. It is absolutely essential that we start thinking about such possibilities and investigate them. As I suggest previously, we may not always like what we see. In the case of China, I do not really see the definitive neo-liberal combination of elements that John mentions as being present there. Instead, there is an exaltation of markets under "market socialism" that is combined with enormous elite and popular ambivalence and even rage against specific markets. There is a residual Maoist redistributive ethic held to by Communist Party cadres that seek to ameliorate the savagery of capitalist development in order to maintain party control and "social order." Non-individualist definitions of persons exist in which boundaries between individuals are hazy, as in the existence of personal connections (guanxi) that cross the state- capital boundary, and there is repudiation of elements of the (post-) Washington consensus at the national-global level (e.g., neo-mercantilism in foreign trade, favored infant industries; see Nonini 2008). This-despite the status perhaps of neo-liberalism as an exception-is what the "normal/normative political culture" in China looks like today, and it is distinctly not a neo-liberal formation. We need to consider such cases seriously.

Donald M. Nonini is Professor of Anthropology and Director of Graduate Studies in Anthropology, University of North Carolina, Chapel Hill. His two most recent books are Local democracy under siege: Activism, public interests, and private politics (2007), and The global idea of 'the commons' (2007).

E-mail: dnonini@email.unc.edu 


\section{Notes}

1. Against Laclau's notion of unfixed discourses, Hall writes, "the articulation of certain discourses to the practices of particular classes has been secured over long periods" (Hall 1988: 140).

2. "In order really to dominate and restructure a social formation, political, moral and intellectual leadership must be coupled to economic dominance" (Hall 1988: 154).

3. By using the plural in what follows, I emphasize the existence of varieties of neoliberalisms.

\section{References}

Bondi, Liz, and Nina Laurie. 2005. Introduction: Working the spaces of neoliberalism. Antipode 37(3): 394-401.
Clarke, John. 2004. Changing welfare, changing states. London: Sage.

Dagnino, Evelina. 2005. "We all have rights, but...": Contesting concepts of citizenship in Brazil. In Inclusive citizenship: Meanings and expressions, ed. Naila Kabeer, 149-163. London: Zed Books. Gray, John. 2007. Black mass: Apocalyptic religion and the death of utopia. London: Allen Lane.

Gramsci, Antonio. 1971. Selections from the Prison Notebooks, ed. and trans. Quitin Hoare and Geoffrey Nowell-Smith. New York: International Publishers.

Hall, Stuart. 1988. The hard road to renewal: Thatcherism and the crisis of the Left. London: Verso.

Holland, Dorothy C., Donald M. Nonini, et al. 2007. Local democracy under siege: Activism, public interests and private politics. New York: New York University Press.

Nonini, Donald M. 2008. Is China becoming neoliberal? Critique of Anthropology. 28(2): 145-176. 